\title{
De blinde vlek in praktijk en discussie rond orgaandonatie*
}

\author{
Herman De Dijn
}

\section{Een paradoxale situatie}

Transplantatie en donatie van organen en weefsels kunnen vandaag (zeker in België en Nederland) rekenen op een brede maatschappelijke aanvaarding. ${ }^{1}$ Over de jaren is de vraag naar transplantatie van organen almaar stijgende en de tekorten raken niet weggewerkt, zelfs niet in een land als België, nochtans een van de koplopers in Europa in orgaandonatie en transplantatie. Op diverse manieren probeerde en probeert de medische wereld dan ook de beschikbaarheid van organen te verhogen. Afgezien van levende orgaandonatie, vooral tussen familieleden of bekenden, is er uiteraard de postmortale orgaandonatie. Het verhogen van postmortale orgaandonatie gebeurde en gebeurt onder meer via allerlei nieuwe juridische regelingen, bijvoorbeeld via nieuwe definities van de dood (zoals de hersendood), of via omschakeling van een 'opting in'- systeem naar een 'opting out'- systeem (dit laatste systeem fungeert in België al sinds 1986). ${ }^{2}$ Of de almaar stijgende vraag tot een blijvend tekort aan organen nen zijn, maar was er toen ik het raadpleegdezal leiden, hangt zeker ten dele af van andere dan louter juridische maatregelen, zoals demografische ontwikkelingen, betere preventie van bepaalde ongevallen en betere behandeling van trauma's, of nieuwe ontwikkelingen in de

* Mijn bijzondere dank aan de twee anonieme reviewers voor hun pertinente opmerkingen bij de eerste versie van dit artikel.

1 Dat geldt ook voor de meeste godsdiensten vandaag (althans volgens hun leidende theologen); zie Harm Goris, red., Bodiliness and Human Dignity. An Intercultural Approach/Leiblichkeit und Menschenwürde. Interkulturelle Zugänge. Tilburg Theological Studies (Berlijn: LIT, 2006); zie ook Bert Vanderhaegen, 'Geven opdat anderen leven. Ethische aspecten van orgaantransplantatie', Acta Medica Catholica 69 (2000): 101-14; en Cor Hoffer \& Huub Zwart, 'Orgaandonatie en de betekenis van levensbeschouwelijke opvattingen', Medische Antropologie 10, nr. 2 (1998): 239-59.

2 In het 'opting out'-systeem - in Nederland Actieve Donorregistratie (ADR) genoemd, in werking tredend in 2020 - moet elke burger zijn keuze inzake orgaandonatie laten registreren. Men kan uitdrukkelijk wel of niet toestemming verlenen, of nabestaanden laten beslissen. Wie geen expliciete keuze maakt, wordt verondersteld 'geen bezwaar' te hebben tegen potentiële afname van organen, kiest dus by default. Nabestaanden mogen wel nog altijd weigeren (om zwaarwichtige redenen), ook al hebben ze geen formeel vetorecht (idem in België). Of een 'opting out'-systeem werkelijk veel uithaalt bij het wegwerken van tekorten blijft echter de vraag; zie in dat verband Erwin J.O. Kompanje, 'Waarom zijn er zo weinig orgaandonoren? De feiten', https:// erwinkompanje.wordpress.com/2017/01/25/waarom-zijn-er-zo-weinig-orgaandonoren-defeiten/ (geraadpleegd 3 april 2019). De cijfers bewijzen dat meer geregistreerde donoren niet noodzakelijk meer organen opleveren; ondanks een verachtvoudiging van het aantal geregistreerde donoren, steeg in België het aantal organen bruikbaar voor donatie de afgelopen tien jaar lang niet evenredig mee; in 2006 waren er dat 833; in 2015 nauwelijks een goede honderd meer; zie https://www.hln.be/nieuws/binnenland/al-247-435-donoren-maar-we-kunnen-nog-meerlevens-redden a971bf20/ (geraadpleegd 1 juni 2019). 
geneeskunde (gebruik van stamcellen bij het regenereren van organen bijvoorbeeld). ${ }^{3}$

In de huidige context van transplantatiegeneeskunde primeert de maatschappelijke de opvatting dat donatie een vrije keuze is van de individuele burger. Die burger kan bezwaar aantekenen tegen afname van organen (en hoeft dat bezwaar niet te motiveren). Familieleden kunnen nog altijd weigeren organen van hun overledenen af te staan. Hoewel dat strikt genomen wettelijk niet moet, schikt het medisch korps zich naar de wens van de familieleden 'ter wille van het ontzien van hun gevoelens' zoals dat genoemd wordt. Sommige ethici en burgers vinden dat er inzake postmortale orgaandonatie eigenlijk geen keuzemogelijkheid zou moeten bestaan. Hier (ook) zou de plicht gelden tot maatschappelijke solidariteit met vitale noden van anderen en die plicht tot (eventuele) donatie zou niet strijdig zijn met de zelfbeschikking van het individu. ${ }^{4} \mathrm{Ik}$ kan hier niet ingaan op deze zowel ethisch als politiek-maatschappelijk betwiste opvatting. Interessant is evenwel dat ook degenen die pleiten voor een plicht tot afstaan van (bruikbare) organen na de dood gewoonlijk toch nog een systeem willen waarin nabestaanden bezwaar mogen aantekenen (maar strikt juridisch gesproken geen vetorecht hebben). Dat heeft niet te maken met de erkenning van onvervreemdbare rechten van de familie, maar veeleer - zo lijkt het - met de vrees van een backlash voor de brede maatschappelijke aanvaarding van orgaandonatie indien zorgverleners onvoldoende rekening houden met de eventuele emotionele weerstand bij familieleden.

In de huidige situatie hebben we te maken met een echte paradox. De vraag naar transplantatie van organen blijft maar stijgen; de maatschappelijke aanvaarding is massaal. Het percentage van als non-donor geregistreerde burgers blijft echter over de jaren in België erg stabiel..$^{5}$ Tegelijk blijven familieleden (ook in een opting-outsysteem) dikwijls weigerachtig om de afname van organen bij hun

3 Ook de mogelijkheid van transplantatie van organen en weefsels afkomstig van bepaalde soorten dieren wordt onderzocht; zie (bijvoorbeeld) de krant De Standaard van 12-13 augustus 2017: 'Virusvrije varkens klaar voor orgaantransplantatie naar mens'.

4 Zie Govert den Hartogh, Afscheid van de vrijblijvendheid. Beslissystemen voor orgaandonatie in ethisch perspectief, Den Haag, Centrum voor ethiek en gezondheid, 2008, www.ceg.nl/uploads/ publicaties/Samenvatting.Afscheid_van_de_vrijblijvendheid.pdf (geraadpleegd 8 mei 2019). Sommigen pleiten zelfs voor een burgerplicht om lichaamsmateriaal na de dood beschikbaar te stellen voor medische onderzoeksdoeleinden; voor een kritische evaluatie van deze opvatting, zie Kristof Van Assche, Laura Capitaine, Guido Pennings, \& Sigrid Sterckx, 'Governing the Postmortem Procurement of Human Body Material for Research', Kennedy Institute of Ethics Journal 25, nr. 1 (2015): 67-88.

5 Het aantal burgers dat zich expliciet als orgaandonor laat registreren in België (met opting-outsysteem) neemt jaar na jaar toe. In 2017 hadden 272.246 Belgen zich geregistreerd als donor, tegenover 244.767 in 2016. Ter vergelijking: 10 jaar eerder, in 2007, telde België 74.331 geregistreerde orgaandonoren. Het aantal burgers dat zich registreert als niet-donor blijft al jarenlang min of meer stabiel. Vorig jaar ging dat over 193.149 Belgen, tegenover 190.678 in 2016 en 191.668 in 2007; zie Persbericht van 19 januari 2018 van minister van Volksgezondheid Maggie De Block op https://www.deblock.belgium.be/nl/aantal-orgaandonoren-ons-land-blijfttoenemen-internationaal-gezien- (geraadpleegd 1 juni 2019). 
overleden naasten effectief toe te staan. ${ }^{6}$ Het bestaan van de paradox van brede maatschappelijke aanvaarding en tegelijk blijvende weigerachtigheid bij een deel van de burgers wordt toegeschreven aan diverse factoren: gebrekkige voorlichting en onvoldoende stimulering van reflectie en bewuste keuze (vandaar in Nederland de nadruk op actieve donorregistratie); irrationele of emotionele reacties bij weigeraars of nabestaanden; of de terughoudendheid bij (sommige) aanhangers van bepaalde religies. ${ }^{7}$

Het bestaan van de paradox wijst mijns inziens op een diepere problematiek die niet of nauwelijks in de publieke discussie ter sprake komt. ${ }^{8}$ Die diepere problematiek heeft te maken met grotendeels 'ondergronds' blijvende opvattingen en bezorgdheden betreffende menselijke waardigheid, meer bepaald de onaantastbaarheid (soms 'sacraliteit' genoemd) van het menselijk lichaam, ook van het dode lichaam. ${ }^{9}$ Indien die noties al ter sprake komen, is het ofwel om ze te verwerpen als irrationeel, ofwel om ze te interpreteren in termen van rechten (bijvoorbeeld, inroepen van lichamelijke integriteit is inroepen van het recht op zelfbeschikking ten aanzien van het eigen lichaam). ${ }^{10}$

6 Diverse bronnen vermelden dat tussen de 10 à 15 percent individuen in België orgaandonatie weigert na overlijden van een familielid; zie bijvoorbeeld ' 1 op de 10 verzet zich tegen orgaandonatie', Het Laatste Nieuws 3 september 2017 (bron: vtm-nieuws.be) https://www.hln.be/ nieuws/binnenland/1-op-de-10-verzet-zich-tegen-orgaandonatie (geraadpleegd 3 april 2019); zie ook het cijfer van 14,2\% (voor 2017) vermeld in Dirk Van Raemdonck, 'Orgaandonatie en Orgaantransplantatie in België anno 2018', http://www.academiegeneeskunde.be/sites/default/ files/atoms/files/Orgaandonatie\%202011.pdf (geraadpleegd 4 april 2019); in De Standaard van 2 mei 2019 wordt het cijfer van 13,5\% vermeld.

7 Zie 'Orgaandonatie botst met geloofsovertuigingen', in De Standaard van 2 mei 2019, p. 6-7. Volgens de redacteur van het artikel zouden de wortels van de weigering (vooral bij joden en moslims) liggen in de interpretatie van religieuze teksten. Dat is betwistbaar, aangezien leidende instanties van die godsdiensten orgaandonatie vandaag helemaal niet verbieden (zie noot 1). Zou het niet kunnen zijn dat achter die weigering niet strikt religieuze, maar veeleer traditionele motieven schuilen die in de eigen religie zelfs niet altijd verstaan of gesteund worden?

8 Zie mijn opiniestuk naar aanleiding van de discussies in Nederland: Herman De Dijn, 'Blijf van mijn lijf', in De Standaard 7 februari 2018.

9 Al deze noties kunnen filosofisch in verband gebracht worden met de specifieke (symbolische) betekenis en waarde van het menselijk lichaam bevestigd in de leefwereld van alle culturen. Over de relatie tussen ethiek en symbolische betekenissen, zie Arnold Burms, Waarheid, evocatie, symbool (Leuven: Peeters, 2011), hfdst. 5; zie ook Arnold Burms, 'Natuur en symbool', in Arnold Burms \& Herman De Dijn, De sacraliteit van leven en dood (Kalmthout: Pelckmans, 2011), hfdst. 1 . Voor analyses van en pleidooien voor het (blijven) rekening houden met de symbolische realiteit van de mens en van het menselijk lichaam in het recht, zie Bart van Klink, Britta van Beers \& Lonneke Poort, red., Symbolic Legislation Theory and Developments in Biolaw (Cham: Springer International, 2016), vooral hfdst. 8, 'The Law and the Symbolic Value of the Body' van Jonathan Herring; en Britta van Beers, Persoon en lichaam in het recht. Menselijke waardigheid en zelfbeschikking in het tijdperk van de medische biotechnologie (diss. Amsterdam VU 2009) (Den Haag: Boom Juridische uitgevers, 2009), zie vooral hfdst. 8, 'De symbolische dimensie van het juridische persoonsbegrip'.

10 De rechten die de wet (in Nederland, maar ook in andere Europese landen) erkent in verband met het eigen levende of zelfs dode lichaam zijn trouwens slechts afweerrechten (tegen ongewenste ingrepen of misbruik), geen claimrechten; zie Van Beers, Persoon en lichaam in het recht, 559 . 
In dit artikel is het niet mijn bedoeling een empirisch onderzoek te doen naar de (vele) diverse, concrete motieven die aan de basis kunnen liggen van de blijvende weigerachtigheid van vele burgers tot orgaandonatie. Wel is het mijn bedoeling de in de praktijk (en de daarmee verbonden discussie) gangbare interpretatie van de persistente weigering van donatie te onderzoeken. De weigerachtigheid bij (sommige) familieleden wordt gewoonlijk geïnterpreteerd als verband houdend met emotionele weerstand. Die weerstand wordt maatschappelijk en ook door de zorgverleners beschouwd als een belangrijk gegeven waarmee rekening dient gehouden te worden, ook al wordt die doorgaans als onredelijk gezien in het licht van de dringende noden van mensen die wachten op transplantatie. Blijkbaar was het precies de aanvaarding van het belang van 'het ontzien van de emotionele bezwaren' van familieleden die uiteindelijk de doorslag gaf bij de goedkeuring van de nieuwe donorwet in Nederland. ${ }^{11}$ De vraag is of die weerstand, ook al wordt er de facto aan tegemoet gekomen, wel in zijn diepere betekenis en belang begrepen wordt. Als dat niet zo is, is het onwaarschijnlijk dat men de paradox waarvan ik spreek echt kan doorgronden.

Wat de diepere, blijkbaar moeilijk in het vizier komende betekenis is die aan de weerstand van familieleden ten grondslag ligt (kan liggen), zal ik onderzoeken in drie stappen: (1) ik onderscheid eerst twee interpretaties van de emotionele weerstand tegen orgaandonatie: een veeleer reductionistische opvatting die die weerstand ziet als een louter subjectieve, sentimentele kwestie; en de veel interessantere opvatting van de filosoof Joel Feinberg die betoogt dat er meer schuilt achter die emotionele weerstand dan men gewoonlijk denkt: het gaat om gevoelens die verband houden met een diepere, maatschappelijk breed gedeelde wijze van zien van en omgang met het dode menselijk lichaam; (2) dan volgt een poging te laten zien dat die complexe visie en omgang deel uitmaken van een (ook in een geseculariseerde maatschappij) breed gedeelde, maar nauwelijks reflexief bewuste kijk op en verhouding tot de (mede)mens en het menselijk leven (en sterven) in het algemeen; (3) op basis van die omweg wordt dan ingegaan op de vraag wat precies schuilgaat (kan gaan) achter de emotionele weerstand bij familieleden en wat de gevolgen van het inzicht daarin (kunnen of moeten) zijn voor de huidige praktijk van orgaantransplantatie.

\section{Het 'ontzien van de gevoelens' van de nabestaanden}

Het lijkt op het eerste gezicht niet zo moeilijk te begrijpen dat familieleden aarzelen om hun dierbaren te onderwerpen aan al wat met orgaandonatie samenhangt: niet alleen het uitnemen van organen, maar ook de hele donorbehandeling op de intensive care met alle gevolgen voor het stervensproces en de manier van overlijden. Zeker bij orgaandonatie na hersendood moeten familieleden aanvaarden dat organen weggenomen worden bij een geliefde die nog de gewone kenmerken ver-

11 Zie https://nos.nl/artikel/2215635-pvda-rol-nabestaanden-bij-orgaandonatie-vastleggen.html (geraadpleegd 29 mei 2019; dank aan Britta van Beers voor de referentie). 
toont van een levende persoon (ademhaling, lichaamstemperatuur, reflexen, enzovoort). NRC-columnist Marjoleine de Vos verwoordde deze situatie als volgt:

'Het lichaam is de geliefde en de geliefde is het lichaam. Zolang dat lichaam, het geliefde lichaam, nog ademt, nog warm is, zolang is de hele geliefde nog aanwezig. Het is bijna onmogelijk om dat ademende lijf te zien als een kapotte machine, hersendood, onrepareerbaar. In dat lichaam woont de eigenaar (...). En dat lichaam moeten we als dood beschouwen, degene die "erin zat" als verdwenen als het woord "hersendood" is gevallen. Het zal wel ouderwets zijn, maar ik kan dat niet. Ook al zeggen nog zoveel ministers en professoren dat het moet.' ${ }^{12}$

Bij weigering van orgaandonatie door de familie is de politiek zowel in België als Nederland dat zorgverleners zich neerleggen bij die weigering, ook al moet dat strikt wettelijk genomen niet. Dat heet dan het ontzien van de gevoelens of het rekening houden met de emotionele bezwaren van de nabestaanden door de zorgverleners. Het bezwaar van de nabestaanden duiden als te maken hebbend met hun 'gevoeligheden' geeft de indruk dat het hen gaat (alleen maar echt kan gaan) om het voorkomen van de pijnlijke gevoelens die orgaanafname bij hun overledenen voor hen zou meebrengen. Wat er voor de nabestaanden op het spel staat herleiden tot 'ontzien van (louter) gevoeligheden' is een typisch utilitaristische reductie. Het is veronderstellen dat het hen eigenlijk gaat om het vermijden van pijn (of, meer algemeen, om hun levenskwaliteit zoals dat vandaag heet). ${ }^{13}$

Niet alleen slaat de utilitaristische visie de bal mis omdat het niet primair of louter om een ontzien van gevoeligheden gaat. Ze is ook grondig fout in haar interpretatie van de gevoelens zelf die bij de nabestaanden (normaal gesproken) effectief aanwezig zijn. Gevoelens zijn geen brute, puur fysiologische reacties op bepaalde verschijnselen; ze veronderstellen het verstaan van en de gepaste reactie op allerlei complexe betekenissen en waarden. ${ }^{14}$ Gevoelens van weerzin en afkeuring bij grensoverschrijdend gedrag (verkrachting of mishandeling bijvoorbeeld) zijn dus geen brute of irrationele fenomenen, het zijn intentionele bewustzijnsacten gericht op betekenisvolle realiteiten ons gegeven in het dagelijks leven. In die gevoelens gaat het niet om onszelf, maar om iets buiten onszelf. De weerzin is er niet omdat wij (subjectief-gevoelsmatig) ergens niet tegen kunnen, maar is er omwille van het besef van de aantasting van iets dat waardevol geacht wordt op zichzelf. Het is mogelijk dergelijke gevoelens tijdelijk buiten spel te zetten (dat kan zelfs nodig zijn om professionele redenen),; maar indien ze bij iemand totaal afwezig zijn,

12 Uit een column van Marjoleine de Vos, 'Het geliefde lichaam', NRC Handelsblad 6 juli 1998.

13 Door zijn enge, sentimentalistische (en reductionistische) visie op ethiek miskent het utilitarisme (of consequentialisme) compleet de rol en betekenis van taboes en symbool in de ethiek; zie voor een indringende kritiek op het utilitaristisch reductionisme: Arnold Burms \& Herman De Dijn, 'Pijn, taboe, contingentie', Tijdschrift voor Filosofie 80, nr. 1 (2018): 3-13.

14 Dat leert de cognitieve theorie van de emoties; zie Nico Frijda, The Emotions (Cambridge, Cambridge University Press, 1986); dit soort opvatting over de emoties is ook te vinden bij Wittgenstein en vele wittgensteinianen. 
spreken we niet van rationaliteit, maar van pathologie. ${ }^{15}$ In de intersubjectieve relaties met anderen, levenden zowel als doden, zijn altijd onvermijdelijk (cognitief-)emotionele houdingen en reacties aanwezig; zonder hen zou er van betekenisvolle omgang geen sprake zijn.

In een bijzonder interessant artikel (al van 1985) heeft Joel Feinberg de clash besproken tussen gevoelens van weerzin bij bepaalde houdingen of handelingen tegenover dode menselijke lichamen enerzijds, en bepaalde reële, legitieme belangen (van individuen wanhopig wachtend op een geschikt orgaan voor transplantatie) anderzijds. ${ }^{16}$ Feinberg ziet in dat de weerzin niet per se hoeft te wortelen in 'irrationele' gevoelens of pure sentimentaliteit, maar te maken kan hebben met wezenlijk humane, intentionele gevoelens tegenover een 'symbolische' realiteit, het dode lichaam van een familielid. Hij aanvaardt eveneens dat het van groot maatschappelijk belang is 'humaniteit' of bepaalde gevoeligheden voor 'onaantastbare' zaken (zoals het dode lichaam) te bewaren. Die humaniteit, verbonden met afkeer voor en afwijzing van bepaalde houdingen en handelingen, zou in het gedrang kunnen komen bij een al te utilitaristische biopolitiek (bijvoorbeeld gericht op het routinematig oogsten van organen voor transplantatie, zoals besproken in het beruchte gedachte-nexperiment van Gaylin). ${ }^{17}$

De morele vraag volgens Feinberg is echter hoeveel gewicht we moeten toekennen aan het ontzien van bepaalde gevoelens (gericht op symbolen) in verhouding tot de reële belangen van patiënten die dringend transplantatie nodig hebben. Moeten we niet bereid zijn zo nodig onze gevoelens te leren beheersen en eventueel op een redelijke manier ondergeschikt te maken aan de reële, legitieme belangen van anderen? Verder is hij van mening dat de flexibiliteit van menselijke gevoeligheden groter is en de kwetsbaarheid ervan kleiner dan dikwijls in het kader van dit soort discussies wordt aangenomen. Allerlei professionelen die op een of andere manier dienen in te grijpen niet alleen op dode, maar ook op levende menselijke lichamen moeten hoe dan ook leren hun gevoelens onder controle te houden zodat ze hun werk efficiënt kunnen doen. Dat blijkt bij hen wel degelijk samen te kunnen gaan met het bewaren van humane gevoelens en met het betonen van de nodige eerbied tegenover hun patiënten (ook al kunnen er situaties optreden waarin ook zij het gevoel hebben ontmenselijkt te worden). Feinberg wijst er verder op dat ook de voorstanders van de onaantastbaarheid van het

15 In de roman van Milan Kundera, De ondraaglijke lichtheid van het bestaan vermeld de hoofdfiguur, de chirurg Tomas, dat hij (ondanks zijn training) een gevoel van blasfemie ervaarde bij zijn eerste operatie.

16 Zie Joel Feinberg, 'The Mistreatment of Dead Bodies', The Hastings Center Report 15, nr. 1 (februari 1985): 31-37.

17 Feinberg verwijst zelf naar het (fictieve) schrikbeeld van dode lichamen als voorraadschuren voor organen en weefsels als geschetst door psychiater Willard Gaylin, 'Harvesting the Dead', Harper's Magazine 240, nr. 1492 (september 1974): 23-28. Gaylin bedacht dit gedachte-experiment om het onaanvaardbare van bepaalde ontwikkelingen naar voor te brengen. Een interessant SF-voorbeeld van dergelijke biopolitiek betreffende menselijke lichamen en organen is te vinden in de Vlaamse kortfilm Samaritan van Douglas Boswell, zie DVD Selected Shorts 9. De beste Vlaamse kortfilms (2009). 
lichaam (doorgaans) aanvaarden dat die onaantastbaarheid niet absoluut is of kan zijn. Bij lijkschouwing bijvoorbeeld moeten de gevoelens het afleggen tegen de noodzaak de gerechtelijke waarheid te weten te komen; tegelijk is dit soort onderzoek gebonden aan bepaalde regels omtrent de waardige behandeling van het dode lichaam.

Het ontzien van de gevoelens van nabestaanden is dus niet zomaar een kwestie van 'louter' sentiment; het is om twee redenen belangrijk en redelijk: niet alleen als (al dan niet pragmatische) tegemoetkoming aan de beleving van de situatie bij familieleden, maar ook in functie van het in stand houden van humaniteit in de samenleving. Maar dat ontzien van gevoeligheden betreffende de onaantastbaarheid van het lichaam heeft, aldus Feinberg, toch grenzen gezien (wat hij noemt) de legitieme belangen van levenden. Verschaft Feinbergs analyse in termen van de tegenstelling tussen symbolische gevoelens en legitieme belangen ons een adequaat inzicht in de problematiek die schuilgaat (kan schuilgaan) achter de emotionele weerstand van familieleden? Vooraleer op die vraag te antwoorden, is een (filosofisch-antropologische) omweg aangewezen die de betekenis van en houding tegenover het dode lichaam als symbolische realiteit situeert in het bredere perspectief van de alledaagse leefwereld met zijn intersubjectieve houdingen en verhoudingen tegenover levenden en doden. ${ }^{18}$ Die bredere situering kan helpen tot een beter besef te komen van wat zich reveleert en van wat op het spel staat in de 'symbolische' emoties specifiek tegenover overleden familieleden.

\section{De betekenis van het menselijk lichaam; het levende en het dode lichaam}

Wij moderne mensen zijn bekwaam tot twee heel verschillende 'wijzen van zien' van het (dode) lichaam: enerzijds de afstandelijke, wetenschappelijke blik; anderzijds de betrokken blik (van eerbied, ontzag, maar soms ook van afkeer, enzovoort) die kenmerkend is voor de intersubjectieve omgang in de dagelijkse leefwereld. ${ }^{19}$ De eerste blik is nauw verbonden met wetenschappelijk inzicht en verklaring en met technisch ingrijpen (ze opent voor ons de wereld van de techno-wetenschap). De tweede blik met intersubjectieve relaties en praktijken (zoals in de zorg) die onderdeel zijn van de dagelijkse realiteit en omgang beleefd in de leefwereld. Complicaties en spanningen ontstaan - onze discussie over orgaandonatie is daarvan juist een frappant voorbeeld - wanneer de twee wijzen van zien en omgaan met mensen (en dingen) met elkaar verweven geraken. Dat is typisch en onontkoombaar het geval in de geneeskundige zorg. Die dient zo objectief gefundeerd en zo efficiënt mogelijk te zijn; maar tegelijk is die zorg fundamenteel ingebed in een ethische dimensie die grenzen kan opleggen aan wat in die zorg mag gebeuren. Dat dergelijke limieten in de geneeskunde aanwezig zijn, is onbetwistbaar. Sommige grenzen blijken universeel aanvaard te worden, zoals het verbod van medische proeven op gevangenen of gehandicapten, de eis van voldoende

18 Ik ontleen het begrip 'leefwereld' aan filosofen als Husserl en Wittgenstein.

19 Ik ontleen de tegenstelling tussen afstandelijkheid (detachment) en betrokkenheid (involvement) aan P.F. Strawson, Freedom and Resentment and Other Essays (Londen: Methuen, 1975), hfdst. 1. 
respect voor levende en dode lichamen, het verbod op trafiek van organen en van klonen. Dat betekent natuurlijk niet dat deze morele en juridische grenzen niet af en toe overschreden worden (dat gebeurt helaas maar al te veel), of dat ze door sommigen niet filosofisch of ideologisch betwist worden.

Een moderne cultuur is niet een cultuur waarin de wetenschappelijke blik en houding alles overheerst en de (traditionele) leefwereld met zijn symbolische onderscheidingen en reacties uitgerangeerd heeft. De moderne cultuur is nog altijd een cultuur. Zij is een cultuur waarin de wetenschappelijke blik en activiteit vrije ontplooiingsruimte gekregen heeft, maar zeker niet alle denken en handelen bepaalt, zelfs niet bij wetenschappers en technici. Ook de neuroloog die van het laboratorium thuis komt, behandelt partner of kind niet als stellen hersenen, maar als wezens met een unieke betekenis die specifieke vormen van (bijvoorbeeld morele) interactie vereisen. Een moderne cultuur is dus een cultuur waarin mensen af en toe uit hun leefwereld kunnen treden en een afstandelijke, 'objectieve' houding (een houding van detachment) kunnen aannemen tegenover de zaken waarmee ze gewoonlijk op een betrokken manier omgaan (involvement). Het is een cultuur waarin wetenschappers die houding van afstandelijkheid op een systematische en methodische manier kunnen en mogen aannemen, zij het binnen bepaalde ethische grenzen. De utopische idee van een op pure objectiviteit gesteunde levenswijze is geen wetenschappelijke idee, maar een ideologische idee bepaald (toch weer) door illusies uit de leefwereld. ${ }^{20}$

In de alledaagse leefwereld zijn menselijke lichamen voor ons niet louter objecten of instrumenten, ze verschijnen als op diverse manieren betekenis- en waardevol. Ze leiden dan ook onvermijdelijk tot allerlei appreciaties, gevoelens, 'reactieve' houdingen en gedragingen op ethisch, esthetisch, erotisch gebied. ${ }^{21}$ Menselijk lichamen zijn dus dragers van 'tertiaire' kwaliteiten, naast de 'primaire' (wetenschappelijke) of 'secundaire' (empirische) kwaliteiten. Die tertiaire kwaliteiten zijn niet irrationeel, ze zijn sui generis; ze zijn, zoals Bernard Williams het uitdrukt, 'tegelijk descriptief en evaluatief. ${ }^{22}$ Het gaat noch om louter objectieve, noch om louter subjectieve kwaliteiten. Hun perceptie is onontkoombaar voor individuen onvermijdelijk participerend in een door culturele betekenissen en waarden bepaalde leefwereld. Wie radicaal niet tot dergelijke (soorten van) percepties en reacties in staat is, wordt niet beschouwd als buitengewoon rationeel, maar als abnormaal. Ook de basis van de geneeskundige zorg, de ethiek, is ten nauwste verbonden met en zelfs ondenkbaar zonder de capaciteit tot perceptie van en reageren op dergelijke kwaliteiten. ${ }^{23}$

20 Arnold Burms, 'Reflections on the Utopian Mind', Algemeen Nederlands Tijdschrift voor Wijsbegeerte 108 (2016): 417-29.

21 De term 'reactieve houdingen' is ontleend aan Strawson, Freedom and Resentment.

22 Zie Bernard Williams, 'The Scientific and the Ethical', in Objectivity and Cultural Divergence, red. S.C. Brown (Cambridge: Cambridge University Press, 1984), 209-28.

23 Zie Herman De Dijn, Drie vormen van weten. Over ethiek, wetenschap en moraalfilosofie (Kalmthout: Polis, 2017),hfdst. 1. 
Hoewel menselijke lichamen objectief gesproken lichamen zijn zoals alle andere (Körper) hebben zij in de leefwereld toch onvermijdelijk een speciale ('symbolische') betekenis: het zijn de betekenisvolle en waardevolle lichamen (Leib) van personen, dat wil zeggen individuen die wij op welbepaalde manieren (dienen te) bejegenen en waartegenover wij allerlei reactieve attitudes en gevoelens (moeten of niet mogen) aannemen. ${ }^{24}$ Het lichaam is geen louter instrument, het is onlosmakelijk intiem verbonden met 'mezelf'. Als ik 'problemen' heb met mijn lichaam, bijvoorbeeld door ziekte of ongeval, heb ik zelf problemen, problemen als persoon. Niet de bewustzijnscapaciteiten van de persoon, maar het lichaam in zijn materiële continuïteit is datgene wat in een soort symboliseringsproces de persoonsidentiteit constitueert. ${ }^{25}$ Dat is de reden waarom wij een persoon ook al is hij psychologisch onherkenbaar veranderd (door dementie bijvoorbeeld) toch beschouwen als (numeriek) dezelfde persoon (die als altijd menselijke waardigheid bezit). ${ }^{26}$ Mijn lichaam constitueert dus mijn persoonsidentiteit, maar omgekeerd identificeer ik mij zelf met mijn lichaam (ook al is dat lichaam mij tegelijk ook altijd enigszins vreemd en kan het soms aangevoeld worden als 'een last'). ${ }^{27}$

Mijn lichaam en zijn onderdelen zijn niet zonder meer van mij (zeker al niet in hun oorsprong). Zoals uit talloze feiten blijkt, kunnen ze ook niet zonder meer door mij naar willekeur gecontroleerd en gemanipuleerd worden. ${ }^{28}$ Het recht op bescherming van het eigen lichaam mag niet verward worden met het recht op beschikking over het eigen lichaam; het laatste volgt geenszins uit het eerste. ${ }^{29}$ Het is bijvoorbeeld niet toegelaten zichzelf als slaaf te verkopen, zich vrijwillig te laten martelen of ledematen te laten amputeren, zich te (laten) klonen, of zelfs op bepaalde manieren te laten gebruiken (zoals bij het 'dwergwerpen'). ${ }^{30}$ Zoals de

24 Het onderscheid tussen Körper en Leib is oorspronkelijk te vinden bij fenomenologen zoals Edmund Husserl en Helmut Plessner.

25 Zie Arnold Burms \& Roland Breeur, 'Persons and Relics', Ratio (new series) XXI, nr. 2 (juni 2008): 34-66; de manier waarop het lichaam in zijn materiële continuïteit de persoon symboliseert, wordt hier vergeleken met de manier waarop relieken een persoon symboliseren via de materiële band tussen bepaalde objecten (of lichaamselementen) en de persoon in kwestie. Deze opvatting over de basis van de persoonsidentiteit gaat in tegen haast de hele filosofische traditie tot de dag van vandaag (zeker de traditie van de philosophy of mind).

26 De basis van de elementaire menselijke waardigheid is niet het bezit van bijzondere of superieure (bewustzijns)kwaliteiten, maar gewoon van geboorte een mens te zijn; zie De Dijn, Drie vormen van weten, hfdst. 6.

27 Ik ga hier niet verder in op het fenomenologische gegeven dat ook het beleefde lichaam altijd een dimensie van vreemdheid (voor de persoon zelf) impliceert; zie daarover (bijvoorbeeld) Bernhard Waldenfels, 'Bodily Experience between Selfhood and Otherness', Phenomenology and the Cognitive Sciences 3 (2004): 235-48.

28 Zie Jonathan Herring, 'The Law and the Symbolic Value of the Body', in Symbolic Legislation Theory and Developments in Biolaw, red. Bart van Klink, Britta van Beers \& Lonneke Poort(Cham: Springer International, 2016), 125-42.

29 Over de beperkingen van het zelfbeschikkingsrecht in relatie tot de eerbied voor de lichamelijke integriteit en de menselijke waardigheid (in verschillende Europese landen), zie Van Beers, Persoon en lichaam in het recht, vooral deel I, hfdst. 3; zie ook deel II, hfdst. 8, 555 e.v.; zie ook Herring, 'Law and the Symbolic Value'.

30 Zie Van Beers, Persoon en lichaam in het recht, 163 e.v. 
wet het uitdrukt, is het menselijk lichaam 'hors commerce'. ${ }^{31}$ De opvatting van het lichaam en zijn onderdelen in termen van (te manipuleren en te verkopen) eigendom is een inadequate en reductionistische opvatting die geen rekenschap kan geven van de reële betekenis en waarde aan het menselijk lichaam in de leefwereld toegekend. ${ }^{32}$

In de leefwereld zijn tevens allerlei inzichten en houdingen aanwezig ook tegenover delen van het lichaam waarvan sommige duidelijk een sterk symbolische betekenis hebben. De houdingen en emoties verschillen van onderdeel tot onderdeel. Het gezicht, het hart, de ogen of de hand zijn niet zomaar onderdelen met een of andere functie (wat ze natuurlijk ook zijn); ze 'definiëren' als het ware wie iemand is, behoren tot zijn of haar persoonsidentiteit. Zo wordt verwonding of verminking van bepaalde delen van het lichaam, vooral van het gezicht, als moreel bijzonder verwerpelijk of erg beschouwd; bepaalde misvormingen van het lichaam kunnen leiden tot ontwijken of bemoeilijken van contact. Het afstaan of verliezen van haar is iets heel anders dan dat van nier of hart (of zelfs bloed). Dergelijke houdingen steunen niet op irrationele, voorbijgestreefde opvattingen: ze zijn, zeker bij moderne mensen, niet het gevolg van onwetendheid betreffende wetenschappelijke inzichten over die lichaamsdelen. Ze zijn gewoon onderdeel van de manier waarop mensen en hun (materiële) lichaam voor elkaar en voor zichzelf in de leefwereld reëel van betekenis zijn. Vergelijk ze met erotische houdingen en gevoelens tegenover het mannelijke of vrouwelijke lichaam of bepaalde delen ervan: ook deze zijn, zoals iedereen weet, niet irrationeel (ongerechtvaardigd); ze zijn arationeel (en hoeven geen rechtvaardiging).

Wat is de betekenis van het dode lichaam? Wetenschappelijk gesproken is het verschil tussen leven en dood geen eenduidige zaak: de dood van het lichaam is wetenschappelijk gezien een gradueel proces waarin verschillende aspecten en fases te onderscheiden zijn. In de context van orgaantransplantatie onderscheidt de geneeskunde hartdood (circulatoire dood) van hersendood (geen hersenactiviteit meer; hersenstam niet meer intact). Het gaat daarbij om twee verschillende, objectief vaststelbare toestanden van het menselijk lichaam. Welke ethische of juridische gevolgen met die objectieve toestanden kunnen of moeten verbonden worden, bijvoorbeeld of in beide gevallen orgaanafname geoorloofd is, volgt helemaal niet uit de medische definities op zichzelf. ${ }^{33}$

31 Zie Xavier Dijon, 'Vers un commerce du corps humain?', Journal des Tribunaux 6233 (9 september 2006), 501-4.

32 Zie ook Herring, 'Law and the Symbolic Value'

33 Voor een discussie over hersendood als een soort 'legal fiction', zie Britta van Beers, 'From Winged Horses to Frozen Embryos. Neomorts and Human-Animal Cybrids. The Functions of Law in the Symbolic Mediation of Biomedical Hybrids', in Symbolic Legislation Theory and Developments in Biolaw, red. Bart van Klink, Britta van Beers \& Lonneke Poort(Cham: Springer International, 2016), 183 e.v. Dat het gaat om een legale constructie zou hieruit blijken dat een hersendode zwangere vrouw toch niet dood wordt verklaard zolang haar baby niet geboren is; zie ook Van Beers, Persoon en lichaam in het recht, 449. 
In de leefwereld betekent de dood een absolute cesuur, het definitieve einde van het menselijke leven, waarbij de gewone omgang onvermijdelijk stopt, maar tegelijk nieuwe, specifieke, maar nog altijd 'betrokken' reacties ten aanzien van de dode vereist zijn. Het mag en moet op de gepaste (rituele) manier begraven of gecremeerd worden. ${ }^{34}$ Men spreekt van het dode lichaam als van een 'stoffelijk overschot'; maar het is niet zonder meer stof, in de leefwereld is het onvermijdelijk een paradoxaal fenomeen. ${ }^{35}$ Het is niet langer de persoon zelf, maar evenmin is het een gewoon object. Het dode lichaam is nog in zekere zin de ander, maar ook niet meer echt de ander.

Tijdens het leven van een persoon was zijn lichaam al een symbolische realiteit, ${ }^{36}$ niet zomaar een lichaam als alle andere, maar een uniek, betekenis- en waardevol lichaam, geëerd met een naam (die naam is zelf weer symbool van een symbolische realiteit). ${ }^{37}$ Het lichaam is de persoon; de persoon is slechts aanwezig en identificeerbaar in en via zijn lichaam. Het dode lichaam is, zoals ook Feinberg het uitdrukt, het symbool van de persoon (die er niet meer is). Niet een 'louter' symbool echter, maar een eerbiedwaardige zaak die de persoon in zijn afwezigheid aanwezig stelt (een 'echt' substituut van de persoon). ${ }^{38}$ Tijdens het leven van een persoon kunnen we gehecht zijn niet alleen aan de persoon zelf, maar ook aan zaken die nauw met de persoon te maken hebben en hem of haar symbolisch representeren: een geschenk dat we van haar ontvingen, een portret of een kledingstuk. Die objecten representeren als het ware de persoon in haar afwezigheid. Die substituten worden met de nodige eerbied en zorg omgeven. Bij het overlijden wordt het lichaam zelf van de persoon een soort relikwie die we op gepaste manieren moeten bejegenen. ${ }^{39}$

Dode lichamen zijn eerbiedwaardig op zichzelf; we nemen hun waarde ernstig om zichzelf, niet omdat wij emotioneel lijden als ze miskend worden. Het dode lichaam blijft een zaak die ook (en juist in de dood) met eerbied bejegend moet worden: het moet 'de laatste eer' bewezen worden. Vandaar de onaantastbaarheid, de 'sacraliteit', van het dode menselijke lichaam (het Latijnse woord sacer

Voorstellen of wetgevingen voor een ecologische manier van 'verwerking' van het dode lichaam getuigen van onbegrip hiervoor; zie bericht in Het Laatste Nieuws 9 november 2018: 'Weg met de doodskist: in Brussel kan je lijk binnenkort laten composteren of oplossen in bad', https:// www.hln.be/nieuws/binnenland/weg-met-de-doodskist-in-brussel-kan-je-lijk-binnenkort-latencomposteren-of-oplossen-in-bad a7f59653/ (geraadpleegd 9 mei 2019); of George Weigel, 'On the Composting of Thee and Me', First Things 8 mei 2019: https://www.firstthings.com/webexclusives/2019/05/on-the-composting-of-thee-and-me (geraadpleegd 9 mei 2019).

35 Zie de beschrijving van 'la dépouille mortelle' bij Maurice Blanchot, L'espace littéraire (Annexe II) (Parijs: Gallimard, 1955), 348-50 (dank aan Arnold Burms voor de referentie).

36 Zie Burms \& Breeur, 'Persons and Relics'.

37 Zodanig dat ook de naam in aanmerking komt om geëerd worden: een wijd verspreid antropologisch fenomeen.

38 Burms \& Breeur, 'Persons and Relics'.

39 Dat gebeurt in alle culturen, zij het op specifieke wijzen; ook in onze verregaand geseculariseerde cultuur wordt het dode lichaam nog altijd gewassen, speciaal aangekleed, opgesmukt en opgebaard. Het Japanse ritueel van het 'afleggen' van het dode lichaam wordt prachtig beschreven in de film van Yojiro Takita, Departures (2008). 
betekent zowel behorend aan de goden als onaantastbaar). Vandaar allerlei wettelijke grenzen ten aanzien van wat het individu zelf met of aan zijn dode lichaam kan laten gebeuren: geen kannibalisme, geen dierenvoedsel, geen cryonica, geen plastinatie (verbod van Körperwelten). ${ }^{40}$ Vandaar het verbod op het schenden van lijken en zelfs van graven. ${ }^{41}$ Aan de doden zelf kan, zoals aan de levenden, iets aangedaan worden dat onaanvaardbaar is: allerlei vormen van oneer. Zelfs foetussen stiekem gebruiken voor medische of industriële doeleinden - af en toe verschijnen zulke berichten in de media - is niet gewoon een inbreuk op de gevoelens of op het eigendomsrecht van de ouders. Het gaat om iets totaal anders; het getuigt van een afschuwelijk gebrek aan eerbied voor onvoldragen menselijk leven en een compleet onbegrip voor de (symbolische) band tussen ouders en kinderen.

De houding tegenover het dode menselijke lichaam als 'heilig' of onaantastbaar bestaat zowel in religieuze als niet-religieuze, in traditionele als in geseculariseerde culturele contexten. Het gaat daarbij om opvattingen en reacties die niet (noodzakelijk) gebaseerd zijn op of gerechtvaardigd worden door (min of meer vreemde) metafysische of theologische hypothesen. Dat bewijst hun voortbestaan in post-metafysische en geseculariseerde contexten. Die opvattingen en reacties zijn gewoon onderdeel van de beleving van de realiteit zoals die gegeven is in de (altijd cultureel geordende) leefwereld. De naam en faam van een dode geweld aandoen, het lichaam of het graf van overledenen onteren: het zijn allemaal vormen van 'morele' schade toebrengen aan de doden. Dergelijke wandaden worden ook in een moderne, geseculariseerde cultuur nog altijd vrij algemeen met grote verontwaardiging afgewezen, niet gewoon omdat ze nabestaanden verdriet aandoen, maar omdat ze de doden (symbolisch) geweld en onrecht aandoen.

\section{Ontzien van gevoelens tegenover honoreren van reële, legitieme belangen?}

In paragraaf 2 besprak ik twee verschillende interpretaties van het ontzien van gevoeligheden. In de reductionistische, utilistische visie is het dode lichaam eigenlijk van geen tel meer ('dood is dood'), alleen de ervaringen, uiteraard van de levenden, zijn van belang. Feinberg ziet in dat de zaak niet zo eenvoudig ligt als de utilistische visie veronderstelt: niet alleen betreffen de gevoeligheden belangrijke 'symbolen' (het stoffelijk overschot van de geliefde persoon), tevens zou het overschrijden van bepaalde grenzen (zoals verbeeld in het gedachte-experiment van Gaylin) kunnen resulteren in ontmenselijkende vormen van biopolitiek ten

40 Zie Van Beers, Persoon en lichaam in het recht, 555 e.v.

41 In Nederland en België staat vreemd genoeg wel grafschennis, maar niet lijkschennis in de strafwet; eind 2017 werd in België een wetsvoorstel ingediend om daar verandering in te brengen; zie https://www.lachambre.be/FLWB/PDF/54/2995/54K2995001.pdf (geraadpleegd 29 juli 2019). 
aanzien van dode lichamen. ${ }^{42}$ Toch vindt hij dat ook 'symbolische' gevoeligheden redelijkerwijze moeten wijken voor bepaalde maatregelen (zoals de wet op orgaandonatie by default) ten voordele van de legitieme belangen van patiënten in reële nood. Is dat een adequate visie op de problematiek?

In het licht van mijn analyse in paragraaf 3 valt er toch wat af te dingen op de visie en de conclusies van Feinberg. De tegenstelling die hij maakt tussen de 'symbolische' gevoeligheden van de nabestaanden en de reële, legitieme belangen van de levenden verschijnt bij hem uiteindelijk als een tegenstelling tussen iets dat toch veeleer subjectief is en iets dat van onbetwistbare, objectieve waarde is en waarvoor het subjectieve eigenlijk moet wijken. Voor de nabestaanden gaat het echter niet om hun privé-gevoelens; het gaat hen om (symbolische) realiteiten, hun geliefde doden, en om reële belangen, de 'morele' belangen precies van de doden. ${ }^{43}$ Anderzijds zijn ook de legitieme belangen van de levenden slechts 'reëel' in en dank zij hun symbolische bepaaldheid. ${ }^{44}$ Wat is, los van de symbolische context, precies het belang van een nieuwe levenskans voor een of ander individu? Dat 'belang' staat niet los van allerlei symbolische betekenissen en categorieën (zoals zelfstandigheid, eer, lichamelijke integriteit, en dergelijke). Het is geen puur 'natuurlijk', maar een verondersteld 'legitiem' (dus uiteraard symbolisch) belang. Solidariteit met de levenden is zelf intrinsiek verbonden met respect voor hun waardigheid, ook deze van hun lichaam. Dat soort respect blijft mutatis mutandis ook na hun dood gelden ten aanzien van het stoffelijk overschot. Het omgekeerde zou pas bevreemdend zijn. In de leefwereld zijn immers noch het leven, noch de dood van een mens louter neutrale gegevens; beide zijn opgenomen in eenzelfde, symbolische betekenis- en waardenkader.

$\mathrm{Nu}$ zijn we eindelijk aangekomen waar we moeten zijn. De ethische afweging is er dus niet eenvoudig een - zoals gewoonlijk, uiteindelijk zelfs door Feinberg, voorgesteld - tussen 'ontzien van de gevoelens van familieleden' en 'de reële belangen van personen in acute nood'. Bepaalde handelingen worden - ook in een geseculariseerde context - door vele nabestaanden gezien als onverenigbaar met de onaantastbaarheid van het dode lichaam van hun geliefden en dus als morele schade aan de dode zelf. In de ogen van (bepaalde) familieleden is de ethische afweging er een tussen het belang van geen morele schade (laten) toebrengen aan hun doden enerzijds, en 'de reële belangen' van op transplantatie wachtende (onbekende) patiënten anderzijds.

Zie noot 17. Meer over de notie biopolitiek en haar oorsprong in Britta van Beers, 'The Best Me I Can Possibly Be', in Personalised Medicine, Individual Choice and the Common Good, red. Britta van Beers, Sigrid Sterckx \& Donna Dickenson (Cambridge: Cambridge University Press, 2018), 200-24.

43 Het lijkt me compleet onredelijk het woord realiteit alleen te mogen gebruiken voor puur empirische zaken en symbolische of 'niet-natuurlijke' belangen (zoals eer of integriteit) geen reële belangen te mogen noemen. Uitgerekend de 'empirist' David Hume hanteerde al het ruimere woordgebruik; zie Herman De Dijn, 'Promise and Ritual: Profane and Sacred Symbols in Hume's Philosophy of Religion', Journal of Scottish Philosophy 1, nr. 1 (2003): 57-67.

44 Vanuit een zuiver objectief standpunt (vanuit 'het perspectief van de eeuwigheid' zoals Spinoza zou zeggen) heeft niets ook maar enig belang. 
Het is helemaal niet vanzelfsprekend hoe een dergelijke afweging dient beslecht te worden. Hoe dan ook is het zo dat in onze maatschappij in bepaalde gevallen het gewicht van (wat familieleden zien als) morele schade duidelijk moet wijken voor een bepaald, belangrijk(er) geacht belang. Dat is het geval bijvoorbeeld met exhumatie en/of autopsie opgelegd om juridische redenen (het vaststellen van causale verbanden in het kader van misdaad- of erfenisonderzoek bijvoorbeeld). De nabestaanden zijn wettelijk verplicht zich bij de forensische activiteiten neer te leggen. Het gaat hier niet om een afweging tussen enerzijds 'gevoeligheden' en anderzijds objectieve belangen, maar tussen veronderstelde rechten van de doden ('rusten in vrede') verdedigd door hun familie en veronderstelde rechten van de levenden of van de maatschappij (om de juridisch relevante waarheid te kennen). Het belang van het ontdekken van de forensische waarheid staat zelf niet op zichzelf. Het heeft te maken met de onvermijdelijk symbolische belangen van personen (en/of van de maatschappij): zorgen dat de schuldige zijn straf niet zal ontlopen; de eigen identiteit kennen; enzovoort.

Een deel van de moeilijkheid bij de morele afweging heeft te maken met het probleem te bepalen welke praktijken nu precies als schendingen van de integriteit van dode lichamen gelden. Zijn de chirurgische praktijken nodig bij orgaandonatie voor transplantatie noodzakelijk schendingen van de lichamelijke integriteit? Waarom zou dat dan niet zo zijn bijvoorbeeld bij levende donatie - iets waar praktisch iedereen toch probleemloos mee instemt ${ }^{45}$ In bepaalde religies bestaat, blijkbaar zonder enige interne contradictie met de vereiste eerbied voor de doden, de praktijk van het wegnemen van weefsels of organen na de dood van 'heiligen' met het oog op de verering van hun relikwieën. Waarom zou het wegnemen van weefsels en organen bij doden met het doel van orgaandonatie voor levenden dan een probleem zijn? Alles hangt er blijkbaar van af of die praktijken ingepast kunnen worden in de globale betekeniscontext van eerbiedige omgang met menselijke lichamen, levende of dode. ${ }^{46}$

Wat de juiste houding tegenover het dode menselijke lichaam precies impliceert, is niet objectief, eens en voorgoed te bepalen. In alle tijden en culturen leert de common sense de plicht om de doden te eren, maar wat die eer precies inhoudt, hangt af van de tijd en de cultuur. Er is dus tegelijk universaliteit en particulariteit. Die particulariteit lijkt de ernst van de concrete, tijd- en plaatsgebonden morele eisen tegenover het dode lichaam te ondermijnen. Maar het besef van die

Vrijwillige, levende donatie tussen familieleden wordt toegelaten en toegejuicht als een daad van supererogatie, ook al betekent dit in feite dat de vrijwillige donor zichzelf schade toebrengt en bepaalde risico's loopt. Of de maatschappij dit vrijwillig lopen van risico en schade moet stimuleren, is helemaal niet evident: het niet verhinderen van het lopen van risico is iets anders dan het toe te juichen; zie Carl Elliott, 'Doing Harm: Living Organ Donors, Clinical Research and The Tenth Man', Journal of Medical Ethics 21 (1995): 91-96.

46 Ik ga hier niet in op de vraag of het afstaan van het dode lichaam voor wetenschappelijk onderzoek en medische training moreel gezien andere problemen stelt dan postmortale of levende orgaandonatie. Toch dit: ondersteuning van personen (en doden) rechtstreeks aan onze zorg toevertrouwd lijkt moreel gezien dwingender dan mogelijke steun aan onbekenden in de toekomst via potentiële vooruitgang in de wetenschap. 
particulariteit is helemaal geen reden om te denken dat de gangbare morele grenzen gewoon overboord kunnen. Het is niet omdat we ons bewust zijn dat onze praktijken contingent zijn, afhankelijk van tijd en plaats, dat die praktijken en de grenzen die ze opleggen voor ons geen gewicht meer zouden hebben. Zij zijn tegelijk het enige dat we hebben. Sommige zaken zijn en blijven voor ons gewoon onaanvaardbaar, ook al weten we dat dit niet zo was of is voor anderen, of niet zo zal zijn in de toekomst (zeker niet van een of andere Brave New World- toekomst). De morele grenzen die ons appelleren en die wij honoreren als zijnde niet te overschrijden, zijn de enige reële morele zekerheid die we hebben - een zekerheid die paradoxaal genoeg (zoals alle reële zekerheid) niet rationeel te funderen is. ${ }^{47} \mathrm{Er}$ bestaat geen objectieve, onafhankelijke meetlat om ethische grenzen te bepalen, geen algoritme om ethische problemen op te lossen. Het idee van de 'reële belangen' van de levenden ingeroepen door moraalfilosofen als Feinberg steunt zelf niet op een soort morele zekerheid die radicaal verschillend zou zijn van de zekerheid betreffende wat moreel onaanvaardbaar is tegenover de doden. Die belangen honoreren veronderstelt zelf ook weer een bepaald ethisch aanvoelen en inzicht betreffende de menselijke waardigheid (van de levenden en van de doden) die deel uitmaakt van de leefwereld en niet steunt op wetenschappelijke of strikt rationele gronden. ${ }^{48}$

In de huidige transplantatiecontext heerst verregaande eensgezindheid dat zorgverleners niet alleen de hoogst mogelijke professionaliteit aan de dag moeten leggen, maar ook de gevoeligheden van nabestaanden die bezwaar hebben tegen orgaandonatie moeten ontzien. Is dat echter waar het echt op aankomt als het die nabestaanden zelf primair om iets anders gaat (kan gaan): de waardigheid en de belangen van hun doden? Is het niet juist een breed gedeelde idee - al sinds de vroegste beschavingen - dat levenden en doden tot één gemeenschap behoren en dat aan het dode lichaam 'de laatste eer' bewezen dient te worden? ${ }^{49}$ Moeten niet alle betrokkenen in de transplantatiepraktijk - en niet alleen de familieleden zich confronteren met betekenis en waarde van het (hersen)dode lichaam en hoe daarmee dient omgegaan te worden? De transplantatiepraktijk, hoe organisatorisch-technisch geavanceerd ook, staat niet buiten de leefwereld van de mensen, maar is zelf onderdeel van een betekenis- en waardenwereld (en niet alleen of vooral een systeem voor het produceren van zoveel mogelijk nuttige resultaten). Als dat zo is, dan dient de gehele professionele transplantatiepraktijk te kaderen in een globale context van eerbied voor de waardigheid van elke mens, ook van zijn of haar dode lichaam. Een dergelijke context vereist onvermijdelijk publieke, rituele vormgevingen. Die rituele vormgevingen veronderstellen, zoals alle ritualiteit, de aanwezigheid van 'verhalen', van houdingen en gebruiken die de betekenis van

47 Zie Arnold Burms \& Herman De Dijn, 'Zekerheid, vertrouwen, scepticisme' (te verschijnen in Tijdschrift voor Filosofie 81, nr.3 (2019)).

48 Over menselijke waardigheid en de feitelijke fundering ervan, zie De Dijn, Drie vormen van weten, hfdst. 6.

49 Het idee van het begraven van de doden als teken van beschaving en als ethische plicht is expliciet te vinden bij filosofen doorheen de geschiedenis: bijvoorbeeld zowel bij de Chinese filosoof Mencius (Meng-tse) (4e eeuw voor Chr.) als bij de moderne filosoof Giambattista Vico. 
het dode lichaam niet negeren, maar integendeel in het licht stellen. ${ }^{50}$ Een dergelijke opvatting van de transplantatiepraktijk is onverenigbaar met elke ontwikkeling die tendeert naar ontmenselijkende structuren en programma's waarin zowel levenden als doden onnadenkend en ongepast gereduceerd worden tot gehelen van te vervangen onderdelen.

Zoals al gezegd, is het niet onmogelijk ook orgaandonatie in de ethische betekenis- en waardencontext op te nemen. Orgaandonatie kan door schenker en familie gezien worden (wordt al gezien) als een posthume daad van naastenliefde via de gave van het lichaam (van bepaalde lichaamsdelen), een daad die niet onverenigbaar hoeft te zijn met eerbied voor het dode lichaam. Ook de zorgverleners kunnen en moeten hun praktijk in die optiek inschrijven. Dat veronderstelt bij hen de ontwikkeling van een hele cultuur van aandacht voor en (ook rituele) omgang met de doden en hun nabestaanden. Familieleden moeten bij orgaandonatie uiteraard de kans krijgen om op gepaste wijze afscheid te nemen van hun geliefden; zij moeten er zeker van kunnen zijn dat de dode resten met respect behandeld worden, niet voor andere doeleinden zullen gebruikt worden, en dat ze die resten op de vereiste wijze zullen kunnen begraven of cremeren. Wellicht is ook veel meer aandacht nodig voor geëigende materiële omstandigheden (afscheidsruimtes, mortuarium, en dergelijke) in de ziekenhuizen waar transplantaties uitgevoerd worden. De huidige politiek om families die orgaandonatie weigeren uit respect voor hun doden niet tot donatie te verplichten, lijkt mij in elk geval een onderdeel van een menselijke, respectvolle transplantatiepolitiek. Het moet daarbij niet zozeer gaan om respect voor de gevoeligheden van mensen, maar om het opbrengen van begrip voor het respect van de nabestaanden voor hun doden.

\section{Besluit}

De ethisch-juridische discussie betreffende orgaandonatie wordt, zoals gebleken is, gekenmerkt door een blinde vlek die verband houdt met: (1) een ontkenning of miskenning van de betekenis van het dode menselijke lichaam, een lichaam dat niet herleid kan worden tot een min of meer bruikbaar stoffelijk overschot; (2) een daarmee verbonden miskenning van de betekenis en van het belang van familiale 'gevoeligheden' ten aanzien van orgaandonatie. Daardoor kan men de paradox van enerzijds algemene maatschappelijke aanvaarding, maar anderzijds persistente terughoudendheid bij vele families onmogelijk duiden, noch begrijpen dat die paradox niet snel zal verdwijnen en zelfs niet hoeft te verdwijnen. De ethische (en juridische) discussie inzake orgaandonatie kan pas ter dege gevoerd worden als ze de zojuist vermelde ont- en miskenningen overstijgt en terug aandacht

50 Dat het belang van rituelen nog steeds begrepen en gehonoreerd wordt, is duidelijk gebleken bij de indrukwekkende repatriëring vanuit Oekraïne naar Nederland van menselijke resten van Nederlandse burgers omgekomen bij het neerschieten van het vliegtuig MH 17 in Oekraïne. Over het doodsritueel (en de evolutie ervan in de postmoderne tijd), zie Herman De Dijn, Rituelen. Waarom we niet zonder kunnen, 2e druk(Kalmthout: Polis, 2018), 226-32. 
heeft voor de reële, symbolische waarden en betekenissen die nog altijd, zij het haast ondergronds, in de leefwereld aanwezig en werkzaam zijn. Dat zal niet eenvoudig zijn omdat de hele discussie vandaag ongemerkt geframed wordt door meerdere elementen die dat bemoeilijken. Ten eerste, door een verenging van de bio-ethische discussie (ook op vele andere terreinen) onder invloed van de heersende revisionistische (vooral consequentialistische) ethiek, een ethiek waarin alles herleid wordt tot een kwestie van ontzien van pijn en streven naar levenskwaliteit. ${ }^{51}$ Ten tweede, door het feit dat de huidige biotechnologische geneeskunde zijn Sitz im Leben (in de betekenissen en waarden van de leefwereld) vergeet, meer en meer een gigantische productiemachine geworden is die door een eenzijdige gerichtheid op succes en beheersing gekenmerkt wordt. ${ }^{52}$ Ten derde, door de steeds grotere invloed op het recht van de enorme wetenschappelijk-technologische en commerciële belangen die zich opdringen en die doen pleiten voor het opgeven van allerlei 'taboes'. ${ }^{53}$

51 Voor een kritische discussie van het revisionisme in de ethiek, vooral in de bio-ethiek, zie De Dijn, Drie vormen van weten, vooral deel II; zie ook Herman De Dijn, 'Revisionist Versus Broad Bioethics and Biolaw', in Symbolic Legislation Theory and Developments in Biolaw, red. Bart van Klink, Britta van Beers \& Lonneke Poort(Cham: Springer International, 2016), hfdst. 9.

52 Zie Herman De Dijn, 'Utopianism in Today's Health Care', in Utopia 1516-2016. More's Eccentric Essay and its Activist Aftermath, red. Han van Ruler \& Giulia Sissa (Amsterdam: Amsterdam University Press, 2017), 185-203.

53 In België wijzigde de wet van 19 december 2018 de vroegere wet van 19 december 2008 inzake het verkrijgen en het gebruik van menselijk-lichamelijk materiaal (weefseldonatie) met het oog op geneeskundige toepassingen of het wetenschappelijk onderzoek; die wijziging gebeurde expliciet met als eerste objectief het aantrekken van meer farmaceutische industrie in België; zie https://www.ieb-eib.org/fr/pdf/20181107-fe-loi-materiel-humain.pdf (geraadpleegd 8 mei 2019). Met andere waarnemers van het domein, merkt Britta van Beers op dat het recht zich meer en meer schikt naar het (politiek-economische) streven naar meer wetenschappelijke vooruitgang, met alle gevolgen van dien voor het respect voor de mens; zie Britta van Beers, Persoon en lichaam in het recht, 478 e.v. 